\title{
Cervical Spine Dysmorphism: Report of Two Unusual Cases of Craniovertebral Junction
}

\author{
Servikal Spinal Dismorfizm: Kraniovertebral \\ Bileşkenin Nadir İki Olgusu
}

Ergün DAĞLIOĞLU, MD, ${ }^{a}$ Yasemin ALANAY, MD, Çağatay ÖZDÖL, MD, ${ }^{a}$ Önder OKAY, MD, ${ }^{a}$ Ali DALGIÇ, MD, ${ }^{a}$ Deniz BELEN, MDa

aNeurosurgery Clinics, Ankara Numune Education and Research Hospital, ${ }^{b}$ Clinical Genetics Unit, Hacettepe University, Department of Pediatrics, Ankara

Geliş Tarihi/Received: 14.09 .2009 Kabul Tarihi/Accepted: 14.04 .2010

Yazıșma Adresi/Correspondence: Ergün DAĞLIOGLU, MD Ankara Numune Education and Research Hospital, Neurosurgery Clinics, Ankara, TÜRKIYE/TURKEY edaglioglu@gmail.com

\begin{abstract}
Craniocervical junction anomalies are rare and their classification is considerably complex. Here we report two unusual cases of cervical spine dysmorphism presenting with the absence of posterior vertebral elements which are also accompanied with Wildervanck syndrome and hydrocephalus. The first case was a 17-year-old female who presented with short stature, broad neck, coarse voice, deafness as well as bilateral lateral gaze paresis. Cervical computerized tomography (CT) and magnetic resonance imaging (MRI) revealed the absence of posterior vertebral elements of cervical spine including partial agenesis of suboccipital bone, rotational deformity of cervical column, Chiari abnormality and cystic cavitation of cervical spinal cord. Additionally dextrocardia, which has not been defined as a feature of Wildervanck syndrome yet, was a marked feature of chest X-ray. The second case was a 32-year-old male presenting with complaints of gait disturbance, dysphonia, severe neck pain, short stature and scoliosis. Cervical X-ray, CT and MRI revealed severe basilar invagination, absence of dorsal elements of first two cervical vertebrae and hydrocephalus. Despite the absence of whole posterior cervical vertebral elements and even occipital bone, basilar invagination was not a predominant feature in the first case. We conclude that presence of a stable ligamentous structure only in anterior cervical column may have contributed to the strength of craniocervical junction and explains the absence of basilar invagination for Case 1.
\end{abstract}

Key Words: Dextrocardia; hydrocephalus; Klippel-Feil syndrome

ÖZET Kranioservikal bileşke anomalileri ender görülür ve sınıflandırmaları oldukça karmaşıktır. Burada Wildervanck sendromu yanında hidrosefaliyle birlikte görülen ve posterior vertebral elemanların yokluğunu içeren iki nadir servikal spinal dismorfizm olgusunu sunuyoruz. İlk olgu kısa boy ve geniş boyun, kaba ses, sağırlık ve bilateral sabit bakış felciyle gelen 17 yaşında bir kızdı. Servikal bölgenin milgisayarlı tomografi (BT) ve manyetik rezonans (MR) görüntülemesi suboksipital kemiğin kısmi agenezini, servikal kolonun rotasyonel deformitesini, Chiari anomalisini ve servikal spinal kordun kistik kavitasyonu ile birlikte vertebraların arka elemanlarının yokluğunu ortaya koydu. Bunların yanısıra akciğer grafisinde şimdiye kadar Wildervanck sendromunun bir özelliği olarak tanımlanmamış olan dekstrokardi saptandı. İkinci olgu yürüme bozukluğu, disfoni, ciddi boyun ağrısı, kısa boy ve skolyoz yakınmaları ile başvuran 32 yaşında bir erkekti. Servikal grafi, BT ve MR görüntüleri ciddi baziler invajinasyonu, ilk iki servikal omurgada dorsal elemanların yokluğunu ve hidrosefaliyi göstermekteydi. Arka servikal elemanların tümünün ve hatta oksipital kemiğin yokluğuna karşın, baziler invajinasyon ilk olguda mevcut değildi. Bu bulgular ilk olguda, sadece anterior servikal kolondaki stabil bir ligamentöz yapının bile baziler invajinasyonu engelleyebileceğini düşündürmektedir.

Anahtar Kelimeler: Deksrokardi; hidrosefali; Klippel-Feil sendromu

Turkiye Klinikleri J Med Sci 2010;30(6):2052-6

ranio-cervical junction (CCJ) abnormalities rarely present with absence of posterior cervical elements and partial agenesis of occipital bone. ${ }^{1-5}$ The absence of posterior cervical vertebral elements around the craniovertebral junction may predispose to instability of this region. 
Besides absence of critical bony structures, congenital stenotic lesions of this region might also contribute to neural compromise and result in disability of the patient. Mechanically, the uppermost cervical vertebrae and odontoid process intracranially causing static or dynamic stenosis of the CCJ area. Brainstem compression at this critical level obstructs cerebrospinal fluid (CSF) flow and manifests clinically as hydrocephalus, respiratory difficulty and may eventually lead to sudden death in extreme cases. The absence of posterior elements and decreased strength of axial supporting structures are frequently associated with basilar invagination. ${ }^{6,7}$

Cervical vertebrae abnormalities are the essential component of cervico-oculo-acoustic (COA) syndrome, also known as Wildervanck syndrome. Characteristic triad of Wildervanck syndrome include Klippel-Feil anomaly, bilateral abducens nerve paralysis with retracted bulbi, namely Duane anomaly, and hearing loss. ${ }^{8-10}$ Here we present two cases of cervical spine dysmorphism associated with unusual CCJ anomalies.

\section{CASE REPORTS}

\section{CASE-1}

Seventeen-year-old female patient presented with torticollis, deafness, short stature and short neck deviated to the right side (Figure 1a). Voice was coarse with phonation disturbances. Neurological examination revealed left hemihypoesthesia and severe scoliosis without any motor disturbance. Ophthalmological examination revealed bilateral lateral gaze paresis. Probable cardiac abnormalities such as dextrocardia, arhythmia and ventricular extra-systoles were also evaluated (Figure $1 \mathrm{~b}$ ). $\mathrm{CO}_{2}$ retention was marked in arterial blood gas analysis. On direct X-rays, multiple segmentation defects were especially marked in the posterior elements of the cervical spine, with fused anterior

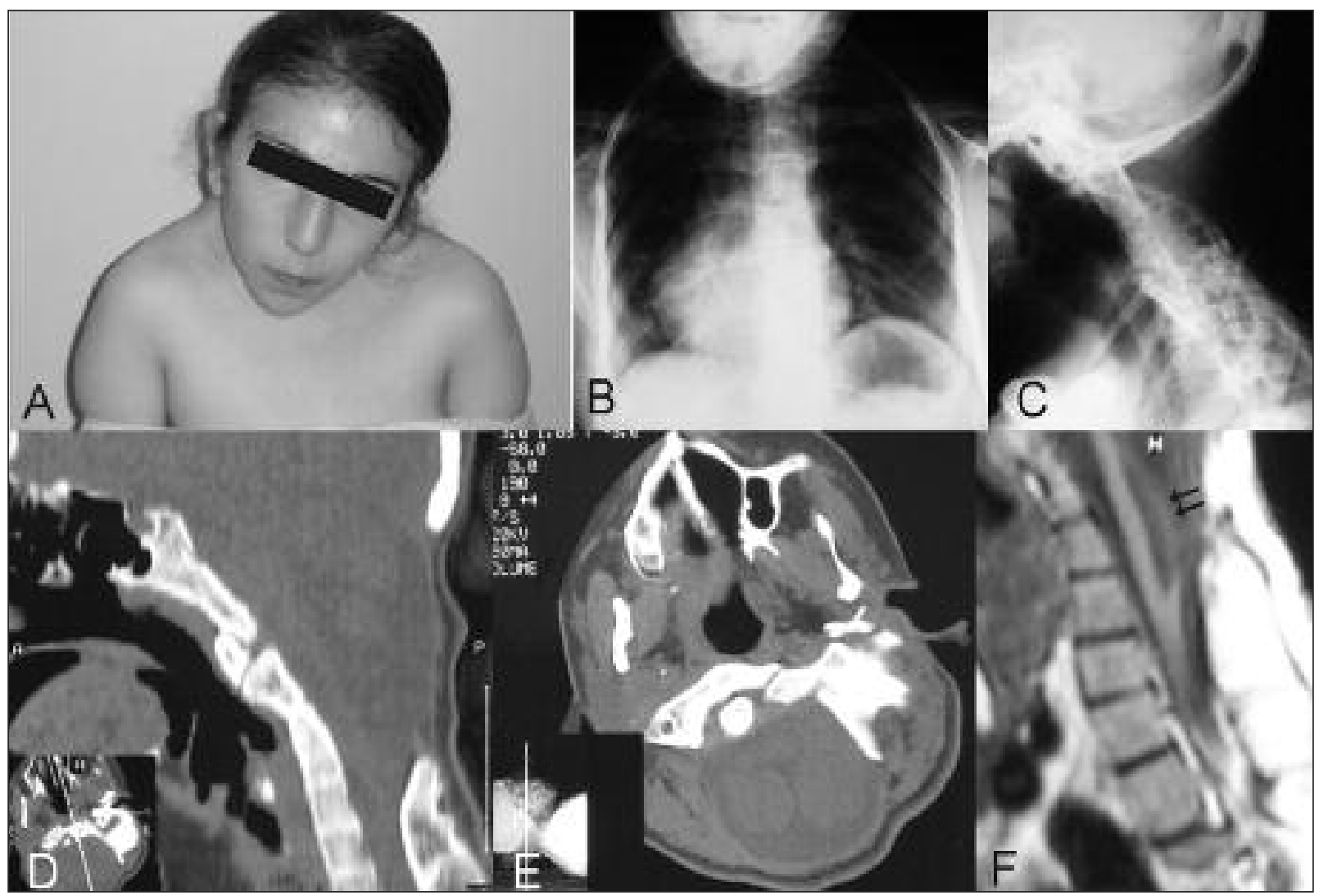

FIGURE 1: A. Photograph of the patient demonstrates the deviation of neck to the right side. B. Chest X-ray reveals dextrocardia. Cervical X-ray (C), sagittal (D) and axial (E) CT scanograms demonstrating absence of posterior vertebral elements and rotational deformity of the cervical spine. F. Sagittal cervical MRI also revealed cystic cavitation within the cervical spinal cord. 
elements of cervical vertebrae (Klippel-Feil) (Figure 1c). Cervical computerized tomography (CT) and magnetic resonance imaging (MRI) showed cystic dilatation of the 4 th ventricle, a cystic cavitation on cervical spinal cord, absence of posterior cervical elements and hypoplasia of the suboccipital bone (Figure 1d, 1e and 1f). The patient's family refused surgical intervention due to associated surgical risks and the clinical condition of the patient was almost stable on three years follow-up.

\section{CASE 2}

32-year-old male presented with complaints of gait disturbance and severe neck pain. Physical examination revealed short stature with scoliosis. Voice was dysphonic and marked ataxia was noted upon walking. Severe basilar impression and absence of dorsal elements of first two cervical vertebrae were demonstrated on X-ray, CT and MR-images (Figure 2). CT and MRI also demonstrated hydrocephalus. Thorough clinical investigations for inherited diseases and syndromes were all negative.

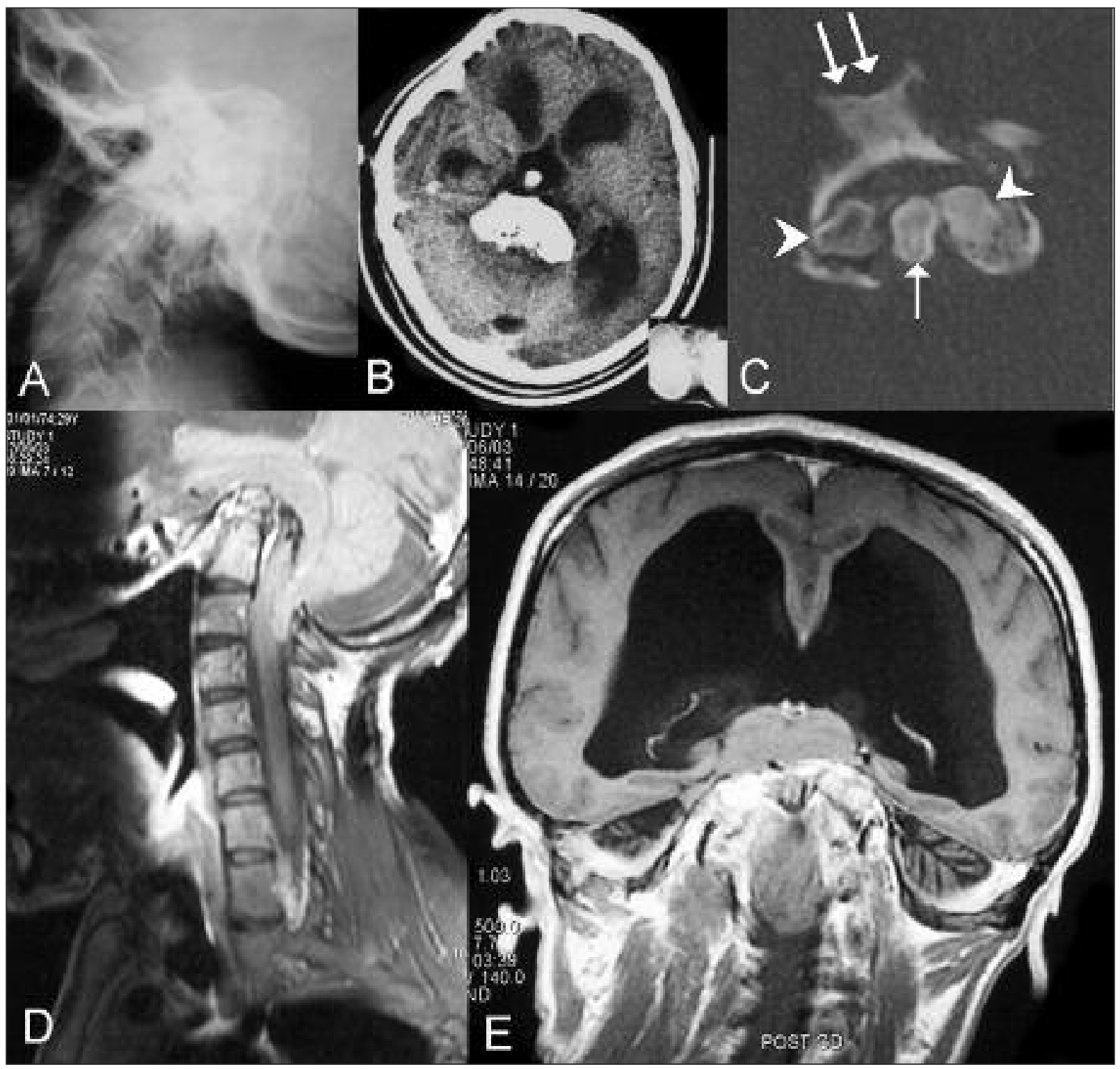

FIGURE 2: A. Lateral cervical X-ray demonstrates basilar invagination and superposition of the upper cervical spine with the axial skeleton of the CCJ. B. Axial CT scan of the same patient also shows bony elements of two uppermost cervical vertebrae and clivus bone with associated hydrocephalus. C. Axial CT scan (bone window) reveals clivus (double arrow), C1 lateral masses (arrowheads) and dens of C2 (arrow) with absence of posterior cervical elements. Sagittal (D) and coronal (E) MRI is typical for severe basilar invagination and hydrocephalus. 
Anterior decompression of invaginated vertebral segment with or without posterior cervical fusion and ventriculoperitoneal shunt insertion were adviced to the patient but he refused surgery despite the benefits were fully explained.

\section{DISCUSSION}

Although the classification of the abnormalities of CCJ may be challenging, they have a unique spectrum and surgical indications are not always bewildering. Mild degree of basilar invagination or Chiari malformation is frequently associated with these anomalies. ${ }^{2,11,12}$ Severe forms of basilar invagination are rare and may also present with hydrocephalus. ${ }^{6,13}$ CCJ anomalies have been previously reported in association with several clinical syndromes such as Klippel-Feil syndrome, COA syndrome, Wildervanck syndrome or Hajdu-Cheney syndrome. ${ }^{6,14,15}$ The Wildervanck syndrome is a rare congenital abnormality characterized with Klippel-Feil syndrome (fused cervical vertebrae), bilateral abducens palsy with retractio bulbi (Duane syndrome) and congenital perceptive deafness. ${ }^{8-10}$ The disorder is almost completely limited to females raising the question of sex-linked dominance with lethality in the hemizygous male. This syndrome may be responsible for at least $1 \%$ of deafness among females. Few cases were reported with MRI findings in the literature. Besides, there were cases with complete and incomplete clinical features of this syndrome. Several developmental osseous anomalies of the CCJ such as vertebral segmentation or occipitocervical bone abnormalities, isolated atlantal stenosis and cerebellar or brainstem hypoplasia were reported to be significant craniocervical structural alterations. ${ }^{8,16-18}$ Abnormalities of the inner and middle ear, microcephaly, mental retardation, and cleft palate have also been reported as the components of this syndrome. ${ }^{9}$

Children with Wildervanck syndrome should be investigated for craniospinal abnormalities with MR imaging. Cervical and bulbar syringomyelia, vermian hypoplasia, tonsillar herniation, basilar impression and platybasia can be accompanied with Wildervanck syndrome. ${ }^{8,19}$ Experience of surgery in patients with Wildervanck syndrome is scarce in the literature and most of them were related to the complications associated with this syndrome. Association of dextrocardia with Wildervanck syndrome which is a marked feature of Case 1, has not been reported previously although few reports emphasized some congenital cardiac problems such as atrial septal defect, cardiomegaly, heart failure or bilateral pleural effusion. ${ }^{9,20}$

CCJ abnormalities, particularly Chiari I malformations that are seen with osteogenesis imperfecta and achondroplasia are also associated with hydrocephalus. ${ }^{71,21}$ However, stenosis of the CCJ predisposes to hydrocephalus, as Case-2 in this report, and obstruction of CSF at a higher brainstem level can be an important reason in severe cases. ${ }^{22}$ We postulate that, the defects in posterior arches may aggravate block of CSF flow as high as third ventricle and mesencephalon level. Absence of dorsal elements of the first two cervical vertebrae of Case- 2 is associated with marked basilar impression and severe congenital abnormalities whereas the case with Wildervanck syndrome has no basilar invagination or impression despite aplasia of dorsal elements of all cervical vertebrae. On the other hand, presence of cervical syringomyelia in this case forms a discrepancy with the explanation to the pathophysiology of the first case.

Several inherited disorders such as osteogenesis imperfecta, achondroplasia and osteocartilaginous disorders are known to predispose to basilar invagination due to decrease in the load bearing capacity of CCJ. Despite the fact that posterior cervical vertebral elements were incomplete in both cases, basilar invagination was not noted in Case 1 where posterior elements of cervical vertebrae and suboccipital bone were completely absent. From the pathophysiological point of view, rather than absence of posterior elements of first two cervical vertebrae, the ligamentous laxity between the uppermost cervical vertebrae and clivus may have contributed to the basilar invagination in Case 2. This is a contradictory finding in terms of the mechanism, however presence of syringomyelic cavitation in this case may be termed as a different entity. Goel et al reported that syringomyelia was 
a tertiary response to the reduction in the volume of posterior fossa regardless of basilar invagination or syringomyelia was the leading cause. ${ }^{23-25} \mathrm{Ac}-$ cordingly, syringomyelic cavitation of the cervical spinal cord encountered in Case 1 is most probably due to present Chiari malformation.

\section{REFERENCES}

1. Chau AM, Wong JH, Mobbs RJ. Cervical myelopathy associated with congenital $\mathrm{C} 2 / 3$ canal stenosis and deficiencies of the posterior arch of the atlas and laminae of the axis: case report and review of the literature. Spine (Phila Pa 1976) 2009;34(24):E886-91.

2. Ahmed R, Traynelis VC, Menezes AH. Fusions at the craniovertebral junction. Childs Nerv Syst 2008;24(10):1209-24.

3. Alvarez Caro F, Pumarada Prieto M, Alvarez Berciano F. Congenital defect of the atlas and axis. A cause of misdiagnose when evaluating an acute neck trauma. Am J Emerg Med 2008;26(7):840.e1-2.

4. Senoglu M, Safavi-Abbasi S, Theodore N, Bambakidis NC, Crawford NR, Sonntag VK. The frequency and clinical significance of congenital defects of the posterior and anterior arch of the atlas. J Neurosurg Spine 2007;7 (4):399-402.

5. Klimo P Jr, Blumenthal DT, Couldwell WT. Congenital partial aplasia of the posterior arch of the atlas causing myelopathy: case report and review of the literature. Spine (Phila $\mathrm{Pa}$ 1976) 2003;28(12):E224-8.

6. Klimo P Jr, Rao G, Brockmeyer D. Congenital anomalies of the cervical spine. Neurosurg Clin N Am 2007;18(3):463-78.

7. Sawin $\mathrm{PD}$, Menezes AH. Basilar invagination in osteogenesis imperfecta and related osteochondrodysplasias: medical and surgical management. J Neurosurg 1997;86(6):950-60.

8. Balci S, Oguz KK, Firat MM, Boduroglu K. Cervical diastematomyelia in cervico-oculoacoustic (Wildervanck) syndrome: MRI findings. Clin Dysmorphol 2002;11(2):125-8.
9. Gupte G, Mahajan P, Shreenivas VK, Kher A, Bharucha BA. Wildervanck syndrome (cervico-oculo-acoustic syndrome). J Postgrad Med 1992;38(4):180-2.

10. Wildervanck LS. [A case of Klippel-Feil's syndrome with abducens paralysis; retraction of the eyeball and deaf-mutism.]. Ned Tijdschr Geneeskd 1952;96(44):2752-6.

11. Chirossel JP, Passagia JG, Gay E, Palombi $O$. Management of craniocervical junction dislocation. Childs Nerv Syst 2000;16(10-11): 697-701.

12. Menezes AH, Vogel TW. Specific entities affecting the craniocervical region: syndromes affecting the craniocervical junction. Childs Nerv Syst 2008;24(10):1155-63.

13. Smoker WR. Craniovertebral junction: normal anatomy, craniometry, and congenital anomalies. Radiographics 1994;14(2):255-77.

14. Ryken TC, Menezes AH. Cervicomedullary compression in achondroplasia. J Neurosurg 1994;81(1):43-8.

15. Santillán Chapa CG, Martínez Coria E, Reyes Marín B, García Gutiérrez G. [Congenital cervical vertebral dysmorphism. Syndromatic integration through radiological clinical correlation]. Acta Ortop Mex 2007;21(3):133-8.

16. Tubbs RS, Oakes WJ, Blount JP. Isolated atlantal stenosis in a patient with idiopathic growth hormone deficiency, and Klippel-Feil and Duane's syndromes. Childs Nerv Syst 2005;21(5):421-4.

17. Graf K. [Congenital deaf-mutism and malformations of the occipital-cervical bones (Wildervanck syndrome)]. Pract Otorhinolaryngol (Basel) 1968;30(2):82-9.
18. Say B, Balci S, Israel R, Yalaz K, Tinaztepe $B$, Erbengi A, et al. Cervico-ocula-acusticus syndrome of Wildervanck. Case report. Turk J Pediatr 1973;15(3):157-63.

19. Eisemann ML, Sharma GK. The Wildervanck syndrome: cervico-oculo-acoustic dysplasia. Otolaryngol Head Neck Surg 1979;87(6):8927.

20. Oe K, Mori K, Konno T, Yoneda T, Ueyama K, Yamagishi M. Ruptured aneurysm of the sinus of Valsalva with Wildervanck syndrome (cervico-oculo-acoustic syndrome), blepharoptosis and short stature: case report. Circ J 2007;71 (9):1485-7

21. Grabb PA, Mapstone TB, Oakes WJ. Ventral brain stem compression in pediatric and young adult patients with Chiari I malformations. Neurosurgery 1999;44(3):520-7.

22. Poca MA, Sahuquillo J, Topczewski T, Lastra R, Font ML, Corral E. Posture-induced changes in intracranial pressure: a comparative study in patients with and without a cerebrospinal fluid block at the craniovertebral junction. Neurosurgery 2006;58(5): 899-906.

23. Goel A, Bhatjiwale M, Desai K. Basilar invagination: a study based on 190 surgically treated patients. J Neurosurg 1998;88(6):962-8.

24. Goel A, Desai K. Surgery for syringomyelia: an analysis based on 163 surgical cases. Acta Neurochir (Wien) 2000;142(3):293-301.

25. Goel A, Sharma P. Craniovertebral junction realignment for the treatment of basilar invagination with syringomyelia: preliminary report of 12 cases. Neurol Med Chir (Tokyo) 2005; 45(10):512-7. 